\title{
Mother, Researcher, Feminist, Woman: Reflections on 'maternal status' as a researcher identity
}

\section{Introduction}

\section{Researcher positionality in qualitative research}

Researcher positionality signifies the 'perspective shaped by the researcher's unique mix of race, class, gender, nationality, sexuality and other identities' (Mullings, 1999: 337). It is a concept central to rigorous critical research in its recognition that enduring social identities confer a status that enables or limits the exercise of power. The salience of different identities is informed by context and social interactions, and varies at the intersection with other constructs of identity such as 'race', social class and gender. The relevance of different aspects of a researcher's status is likely to depend on the topic of research inquiry and the identity status of those with whom the researcher is interacting, and this relevance may well shift throughout the research process as the researcher (re)positions her/himself, and is, in turn, (re)positioned by participants.

An awareness of researcher positionality promotes an understanding of and response to the changing balance of power that pervades and impacts on the research process (e.g. Lavis, 2010). This is because, by making explicit the assumptions, roles and performances that the researcher brings to bear upon the research process, transparent and trustworthy interpretations of the data can be made. Being able to recognise and negotiate one's identities as a researcher is therefore an important reflexive tool at all stages of the research process.

However, any discussion of positionality needs to consider the role of affect and emotionality in the research process. Differences in moral and political stances can lead to researchers feeling 'alien' to their participants, despite apparent socio-demographic similarities, and such discomfort can work to shape all aspects of the research process in ways which cannot be anticipated (e.g. Jansson, 2009). Furthermore, dealing with such emotions may present particular challenges when adopting particular epistemological approaches (such as feminism), since such approaches may encourage a level of emotional engagement with self and others which, in practice, may be at odds with the demands of 'good research' (see Ryan-Flood and Gill, 2010).

Critics of the use of positionality in social research have identified problems with researchers making assumptions about what it means to be a member of a particular community in ways which are incongruent with community members themselves (Ganga and Scott, 2006). Critics also point to the perpetuation of Western bias and the imposition of neo-colonialism which inhibits meaningful 'positional' engagement in fieldwork (Sultana, 2008). Furthermore, attention to positionality always runs the risk of over-looking some aspects of position while over-emphasising the importance of others (see, for example, Riessman (1987) in her exploration of gender and nationality).

Exploration of researcher positionality over the past decade has produced insights into how a researcher's gender (Pezalla et al, 2012), 'race' (Brown, 2011), age/generation (Ganga and Scott, 2006), social class (Hurst, 2008) and cultural status (Weiner-Levey et al, 2012) shape the research process. More recently, the role of fluid and self-determining researcher statuses such as 'married/unmarried' status (Takeda, 2012), political membership (Jansson, 2010) and 'academic/peer researcher' status (Ryan et al, 2011) have also been explored. However, while an examination of the role of gender has produced many insights, there has been little development in exploring specific aspects of gender. In 
particular, there has been little examination of how the role of a researcher's maternal status shapes the research process, particularly when the research process is informed by feminist principles.

\section{Maternal status as a researcher identity}

It is argued that the status of 'mother' is central to how women define themselves and other women (e.g. Phoenix et al, 1991), although it is important to recognise that 'motherhood' (and, indeed, 'being child-free') is a dynamic status which evolves throughout one's maternal career (Miller, 2005). Social and institutional changes may mean that motherhood is no longer the 'gender fate' that it once was (Beck \& Beck-Gernsheim, 1995), but there remains a questionable moral status attached to the position of (female) childlessness. Within this category, the sub-categories of 'childless by choice' and 'childless by circumstance' (Cannold, 2004) prescribe a further moral hierarchy to this status. Despite the rise of feminism, pro-natalist discourses which construct 'motherhood' as natural, inevitable and an intrinsic aspect of femininity, remain pervasive. In contrast, 'non-motherhood' is constructed as unnatural, unwomanly and is characterised by deficiency and loss (both physical and emotional). Indeed, Letherby (1994) points out that the very status of 'childlessness' is defined by lack - women are childless, 'barren', non-mothers $\left[{ }^{1}\right]$. Such powerful discourses mean that child-free women must continually 'account for themselves' (Morell, 1994: 69) through extensive emotional work and identity management (Letherby, 2002). Such work adds a further dimension to the notion of a gendered 'emotional labour' identified by Hochschild (1990) and has relevance for those researchers who are female and who may be researching the topic of motherhood while remaining child-free themselves. For such researchers who also identify as 'feminist', negotiating these limiting pro-natalist discourses presents a further challenge because such negotiations raise questions about whether performing emotional work in the course of social research is appropriate, particularly when such work may not always result in the furthering of feminist goals $\left[{ }^{2}\right]$. Different challenges present themselves for researchers who are mothers and who must negotiate complex tensions produced by competing discourses which constitute the roles of 'successful academic' and 'good mother' (see Raddon, 2002) - tensions which are further complicated when those academics and mothers also claim the identity of 'feminist' (David et al, 1996) $[3]$.

The purpose of this article is to open up a dialogue about how 'maternal status', as an integral aspect of the status of woman, shapes the research process when exploring a topic which inevitably foregrounds the salience of this status. Thus, our aim is to explore the tensions which arise when our identities as mothers, researchers, feminists and women conflict in the pursuit of investigating experiences of motherhood. We draw on two studies that we have conducted separately: one on the transition to second-time motherhood (Frost, 2006) conducted by Nollaig, and the other exploring mothers' experiences of parenting young offenders (Holt, 2009) conducted by Amanda. In order to enable readers to understand the context and conduct of the studies we briefly describe ourselves and each study before considering how our maternal status shaped the research topic, our selection of methods and our research practice. We do this by reflecting back on our research diaries and analysing our own and each other's extracts from them and discussing its implications for both our own research practice and for research practice with mothers more broadly.

\section{The Research Studies}

Nollaig was a mother of two children aged 18 months and 4 years old when she conducted her study. She undertook the research as part of her doctoral studies following professional practice for several years as a psychodynamic counsellor. The longitudinal study aimed to explore the experiences of mothers who were making the transition to second-time motherhood. It was conducted with seven 
participants who were interviewed at three monthly intervals for a year, starting when they were six months pregnant with their second child. The participants had been recruited from London (UK) through parenting networks and snowball sampling. A table of the demographics of the participants is shown below:

[TABLE 1: Second-time Mothering: Table of Participants]

At the research outset, Nollaig commented on her complex maternal identity going into the field, where her dynamic and evolving 'mother status' is apparent:

The distinction between being a 'new' mother of two children, and an 'experienced' one seems very blurred. On the one hand I feel that I have successfully traversed the new baby stage, twice, but on the other hand I still do not feel confident or expert in being a mother to two children. The participants are situated between these two experiences but I too feel positioned as an 'inbetweener'.

Amanda was child-free when she conducted the study. She undertook the research as part of her doctoral studies and following professional practice as a research officer working with young people and families. The study aimed to explore the experiences of mothers whose children were involved in the youth justice system. The fifteen participants had been recruited through the parenting co-ordinators at four local Youth Offending Teams (YOTs) across the South of England and were each interviewed once. A table of the demographics of the participants is shown below (note that, for three participants, not all of the data could be obtained):

[TABLE 2: Mothering troublesome young people: Table of Participants]

At the research outset, Amanda commented on her experienced lack of maternal identity, which, when intersected with perceived differences in age and social class, produced its own feelings of discomfort:

Leaving the council estate where my first interview took place, I feel like a posh schoolgirl - while wide-eyed and nodding, I felt physically exposed by my lack of experience. Not only do I know very little about school reports, exclusions, teenage boys, the school run and all those everyday details of parenting, but my lack of understanding the visceral and emotional aspects of the mother-son relationship makes me feel failed as both researcher and woman.

\section{Maternal status shaping research topic}

Acknowledging the role of personal autobiography in social research has long been central to feminist methodologies (Oakley, 1981) and many feminist researchers have claimed that their personal experiences of motherhood have driven the nature of the research topic (David et al, 1996). This is particularly the case when the researcher has some autonomy over the nature and direction of the research, such as when it forms part of the researcher's doctoral studies. Thus, Gayle Letherby (2000) writes about her personal experiences that motivated her to research women's infertility and voluntary childlessness; in her research examining the experiences of lone mothers navigating the welfare system Lizzie Ward (2007) references her 'intellectual autobiography' by describing the salience of her own experiences to the research topic; Kyla Ellis-Sloan (2012) talks about her own past experiences of being a teenage mother in shaping her decision to explore the lives of current teenage mothers.

In our research - which also formed part of our doctoral studies - our status as 'mother' and 'nonmother/child-free' was of significance in differing ways. Like the research outlined above, Nollaig's 
interest in researching the experiences of women becoming mothers for the second-time was provoked by her personal experience of having a second child, as she reflects:

Having worked as a psychodynamic counsellor with women who were mothers, and aware of the inherent assumption in much of the psychoanalytic literature of 'one child-one mother' relationships, my own subsequent experience of second-time motherhood challenged these ideas. Thus, the goal of my research became to use psychoanalytic ideas to examine the expectations and realities of mothers preparing for and then entering second-time motherhood.

However, as a non-mother, Amanda had no such autobiographical narrative available on which to draw in explaining her reasons for her choice of research topic, which aimed to explore the experiences of parents of 'young offenders' in light of pervasive 'blame the parents' political, legal and cultural discourses:

At times, I attempted to cobble a narrative together by describing how, as a teenager, my brother had been in trouble with the police, and my parents were therefore open to accusations of blame. But this was not why I had chosen the research topic. In fact, my original doctoral proposal aimed to explore the experiences of siblings of young offenders, but two months into my doctoral studies I realised that, with so little theoretical and empirical research on this topic, a switch to examine parenthood would be a more academically fruitful avenue. Thus, ultimately (although perhaps not initially) my research topic choice was strategic rather than personal.

The absence of an autobiographical narrative felt problematic to Amanda because it raised the question about legitimacy if a researcher has no personal experience of the research topic. This issue felt particularly acute given Amanda's claim to the status of 'feminist researcher' and the long history of feminist research being embedded in the idea of personal autobiography and that 'the personal is political'.

\section{Maternal status shaping access to participants}

A very practical consequence of maternal status when researching mothering concerns the ease of accessing participants, which is likely to shape both the choice of research topic and subsequent methodological decisions. For Nollaig, accessing second-time mothers was a relatively simple process as she drew on personal and professional parenting networks to contact mothers directly and developing a snowball approach to recruit others to the study.

In contrast, Amanda knew very few mothers and had no access to the social networks which Nollaig tapped into. She therefore sought a more formal route of accessing participants through statutory agencies - specifically through Youth Offending Teams (YOTs). Of course, this is not to suggest that the nature of her research had no impact on her method of participant access - utilising agencies within the youth justice system is the obvious method when the research aim is to explore experiences of families who are involved in that system. However, we would also argue that having particular groups of participants closed off to a researcher - because of particular aspects of a researcher's identity - shapes the initial research topic and aim in the first place.

Even when feminist researchers are able to tap into those female networks, the lack of a shared maternal status may prove to be a barrier in participant recruitment, as Kirsty Budds (2013) reflected in her doctoral research about women's experiences of being an 'older' mother: 
I have little first-hand knowledge of the ways of speaking and typical discursive and conversational devices and resources employed by mothers. This was most acutely felt when I attended a post-natal class to recruit women for my study. As the only woman without a child, I found it incredibly difficult to approach the women and know what would be appropriate to say for a good opening to a conversation. I was the only one in the room who did not have the same thing in common as all the rest - their babies. (Budds, 2013; 207)

Such barriers raise interesting questions about who feminist research is available to - at least when the topic concerns experiences of motherhood.

\section{Maternal status shaping method}

We each selected the 'narrative interview' as our choice of research method for data collection. Narrative methods start from the assumption that people use stories to make sense of their own lives, and to present themselves and their experiences to others (Sarbin, 1986). Narrative interviews tend to be open and 'unstructured' so that narrators are free to construct accounts around the issues that are of most personal significance to them, and are particularly favoured by feminist researchers who find that more open-ended interview approaches enable the researcher to position themselves non-hierarchically in relation to the women-participants they speak to (see Oakley, 1980). While there are a number of specific analytical approaches to using narrative, critical narrative analysis (the approach adopted by each of us) recognises the co-construction of the account, both within the interview and in its subsequent interpretation and re-presentation. The text is kept as whole and un-fragmented as possible and the researcher's interventions are included as part of the account and its analysis. The context and interpersonal relationship of the story construction are considered alongside the content. Thus the researcher brings their subjective perspective to the 'objective socially constructed text' (Emerson and Frosh, 2004).

However, despite us both drawing on narrative methods, we each provided different explanations for this choice in our reflexive field notes, with each explanation nevertheless closely tied to our maternal status. For Nollaig, narrative approaches seemed particularly important given her 'insider status' as a (second-time) mother (Phoenix et al, 1991). As a mother conducting research with other mothers about motherhood, Nollaig noted:

The risk of recognition of myself in the accounts of other mothers posed a threat to the rigour of the qualitative inquiry at all stages of the research process: from data elicitation to interpretation and presentation. Thus, a narrative approach to both data collection and analysis was rationalised as the method that best enabled me to remain open to and grounded in the data, to gain insight into how others constructed their identities as mothers preparing to and then having a second child. At the same time, narrative methods also enable me to attend to my role in the research process, and particularly in the interview process.

In contrast, Amanda explained her method of using narrative interviews in a very different way, albeit one that was still framed by her maternal status.

There may also be other, more personal aspects of myself at play in the research process. I wonder if my selection of the narrative interview had as much to do with my own lack of professional confidence in knowing 'what to ask' parents than any theoretical motivation. Furthermore, is the narrative interview's production of such a taciturn researcher stance 'borne of defence' by creating a safe place for the researcher which avoids role uncertainty and selfdisclosure, as Gough (2003) suggests? ... [...]....My lack of experiential knowledge of (normative) 
parenthood made me feel that I lacked legitimacy in attempting to understand parents' experiences.

Furthermore, Amanda chose not to analyse the data through narrative analysis, but through discourse analysis. She later reflected on whether this methodological decision was also 'borne of defence':

I was not aware that my choice of using discourse analysis was in any way driven by my maternal status, but did its focus on 'language' (rather than 'experience') allow me to legitimately avoid any further interrogation of my own (non)maternal subjectivity?

Thus, while Nollaig's choice of method operated around her attempt to avoid imposing her own mothering story on others, Amanda's was explained in terms of her attempts to avoid challenges to her legitimacy as a 'non-mother doing research motherhood'.

\section{Maternal status shaping research practice}

Within a shared identity of 'womanhood', maternal identity may facilitate or inhibit intimacy and a shared common repertoire. Researchers of motherhood (e.g. Letherby, 2000; Ellis-Sloan, 2012) have commented that their disclosure of having similar 'mothering' experiences to the participants enabled them to break down some of those 'them' (i.e. researcher) and 'us' (i.e. participant) barriers which research interviews often produce, making conversations feel awkward and unnatural for both parties. While remaining mindful of Finch's (1984) observation that 'using' an insider position to extract data from participants can be ethically problematic, a researcher's own experience of motherhood can function as a discursive resource within the interview setting.

In Nollaig's study, the point at which she disclosed her maternal status to the participants produced clear changes in the interpersonal discourse. Nollaig disclosed that she was a mother of two children approximately halfway through the first interviews that she conducted with each woman.
I found myself being questioned on my own practices as a mother and wondered if some participants were exploring my experiences to inform their own. On the other hand when participants were told that I was a mother of two (halfway through the first interview) I found their accounts to change in tone and style. Most noticeable was the increasing use of phrases such as "You know" and stories that seemed to have unspoken endings based on a shared knowledge assumption between two mothers of two children. I wondered if these women felt less need to position themselves as ideal mothers and could speak more openly about the experiences as they found them.

Awareness of this decision raised the question of whether the participants' knowledge that Nollaig's interest in the topic arose from personal experience enabled some mothers to voice the gap between expectations and reality with less fear of criticism and judgement from her.

Yet for some women and in some moments during the interviews, Nollaig's disclosure of being a mother of two children herself seemed to produce a sense of over-intimacy which in turn led to discomfort and awkwardness for her as tensions between being an 'academic researcher and' a 'mother' manifested:

At times the resonance of the stories I was being told caused me discomfort or reminded me that I was a mother at a time I was trying to be other than a mother - a researcher. For example, when one participant told me of having been up all night with a crying baby on a day that had followed a similar night for me. 
Discursive resources based on personal experiences of being a mother are clearly not available to childfree researchers. In such cases, perhaps the most salient shared identity that a researcher can draw on to facilitate the interviews with mothers is gender. However, with the perception of motherhood as the ideal of femininity (Morell, 2000) the question of how to perform femininity without a 'mother' status becomes prominent.

While Cassell (2005) suggests that identity work is performed in interviews to decrease the ambiguity of the interview situation, Amanda found that one solution to this conundrum was to perform identity work to increase ambiguity:

I worked hard to avoid disclosing my own non-mother status in case this acted as a barrier. A second solution was for me to draw on heavily what other mothers had said, often by directly quoting them so that I could perform the role of a 'quasi-mother'. I also would find myself emphasising my experience of previous parenting research. To some extent, this allowed me to tap into the discursive resources that mother-researchers have access to, but through drawing on 'authoritative knowledge' rather than 'experiential knowledge'.

However, such practices of identity management pose both theoretical and practical problems: theoretically, they raise the question of what such practices of non-disclosure imply about research which claims to be feminist? More practically, it seems that such practices nevertheless had little impact, as Amanda's own 'non-mother status' was read off her by at least one participant, when Bee exclaimed towards the end of the interview: 'Don't ever have children!'

In other contexts, it may be that explicitly not self-identifying with mother-participants achieves certain functions, especially when researching mothering issues that are particularly morally-loaded. For example, in an interview about her research into 'full-term' breastfeeding (see Fairclough, in press) Charlotte Fairclough commented:

I think, weirdly, not being a mum was really a useful thing for me while I was doing my research, because I wasn't a them or an us. It allowed me to ask some basic questions that I wouldn't have been able to otherwise. Everything has got very heated, and very moralised. How you feed your kids is no longer a personal decision. There's this idea that you can breastfeed your way out of poverty, or if you don't breastfeed your kid's going to be fat or have a low IQ....it's all got a bit out of hand. (Williams, 2012).

Other researchers (e.g. Budds, 2013) have described techniques such as drawing on the rich and detailed experiences of family members who are mothers so that their participants feel that they are more likely to understand their own experiences. However, it is important to recognise that 'insider status' may be more important to the researcher, or the gatekeepers, than to the participants themselves: Ellis-Sloan (2012) describes how, in response to her attempts to draw parallels between her own and her participants' experiences as 'teenage mums', her participants continued to draw distinctions between them.

\section{Participant Positionality}

Ways in which a researcher's maternal status enables and/or limits the possibilities for the performance of a participant's identity during the course of the research interview should not be overlooked. While the need to self-police representations of the self as a 'good mother' is well-documented (e.g. Miller, 2005; Marshall \& Woollett, 2000), little has been discussed about how researchers work during 
interviews to enable mother-participants to maintain a morally-acceptable position. For example, Amanda's research explored the potentially problematic issue of mother-participants feeling 'blamed' for their child's offending in a context where mothers are routinely blamed both in academic and cultural discourse (Caplan \& Hall-McCorquodale , 1985; Jackson \& Mannix, 2004). As Amanda noted:

I found myself asking mothers about their experiences of their child 'getting into trouble' as a euphemism for a range of adolescent criminal acts such as $G B H$, aggravated burglary and attempted murder - this was all a conscious attempt to indirectly avoid positioning the participant as a 'bad mother' which the explicit listing of such criminal acts might invite. However, my avoidance of categorising myself in terms of my maternal status meant that there was no onus on me to perform 'good motherhood' myself.

However, it would seem that the need to enable participants to perform 'good motherhood' is not exclusive to contexts when participants are particularly at risk of being positioned as 'deviant' mothers. Nollaig's participants were white, middle-class, professional women who were married and who enjoyed particular privileges which are not available to all mothers. Yet perhaps in an unconscious recognition and mirroring of the women that were recruited to her study as being similar to her, Nollaig noted in her research diary:

I found myself enabling participants to perform 'good motherhood' in the interview by drawing on my knowledge and experience of pervasive negative discourses of mothers who also work outside the home. I framed my questions in positive terms such as "What has the return to work given you?", which I believe enabled participants to respond openly with discourse that may not be acceptable in other contexts by saying "partly what going back to work has given me is just a time when I'm not worrying or thinking about them [the children]".

However, in contrast to Amanda's research experience, Nollaig's maternal status as a mother meant that the need to perform, or to resist performing, 'good motherhood' was never far from the interview. As her field-notes revealed:

I found myself having to resist being a 'good' mother, when one baby cried for 30 minutes during an interview and her mother, the participant, showed no sign of attending to her, whilst also talking of the strains of having two children. I just wanted to go and pick up the baby, as I would if it had been my own child but felt I had to stop myself from doing so in order to maintain my role as a researcher and not a mother"

It is interesting that these two roles - of mother and of researcher - were constructed as discrete entities in Nollaig's discourse. Yet each of these roles are utilised in specific ways to negotiate dominant discourses of 'good motherhood'. In the first extract above, Nollaig draws on her maternal identity and past experiences of mothering to allow her participants to talk positively about work outside the home, enabling them to keep their performance of 'good motherhood' intact. However, in the second extract, Nollaig's refusal to attend to the crying baby is fundamentally more resistant to the notion of 'good motherhood'. However, this 'practice of resistance' was only available to the 'researcher' aspect of Nollaig's identity. This raises interesting questions about the extent to which different identities - as women, mothers, feminists and researchers - enable and/or limit the exercise of power to produce transformative change in terms of the feminist goals of the research.

Research interviews also enable the researcher herself to perform her own emotional work around her identity. Nollaig recounts one such experience which appeared to also facilitate further identity work for the participant through a collaborative process: 
In one interview the participant started talking about her place in her own family as a second child and how she had felt that she had not received as much attention as her older sibling had, and did not want to repeat this for her own second child. However as the participant continued her account and told me of how she endeavours to take responsibility for ensuring that not only she but her husband and mother-in-law (both involved in the childcare) make efforts to pay equal amounts of attention to both children I found myself responding to her as though she were the oldest child in her birth family. It was only after some confusion that she clarified that she was the oldest girl but the second sibling with an older brother. As an oldest girl myself I wondered if I had identified with some of the participant's concerns for accepting responsibility for younger siblings and translated some of that to mothering my own children? Had we, in the course of the interview, re-positioned ourselves from being mothers talking to each other to oldest sisters talking to each other?"

A review of the interview transcripts from Amanda's research showed no such emotional work in terms of 'accounting for herself' as a non-mother. This was enabled by her decision to not disclose her maternal status to the participants, yet her avoidance of performing such emotional work means an avoidance of challenging the pervasive discourses of deficiency and lack which surround 'nonmotherhood'. Might a more progressive action have been to raise her maternal status from the outset and explain why it makes her a credible subject - as a researcher, as a feminist and as a woman - for interviewing mothers about motherhood?

\section{Conclusions}

In this paper, each of us has reflected on our own and each other's research field notes to illustrate how each of our maternal statuses - as a 'mother' and as a 'non-mother/child-free' - may have shaped our research into experiences of motherhood. This shaping may begin as early as the formation of a research idea, and in the practical implications for accessing participants that involves. It may also shape the research method and analytic framework: Nollaig's 'positivist' concerns about 'researcher objectivity' and Amanda's 'anti-positivist' concerns about 'experiential legitimacy' appear to both be the product of an epistemological anxiety produced by the fear that a researcher's maternal status may damage the credibility of the research. Maternal status may also produce particular conflicts during research practice, evidenced by Nollaig's conflict between performing 'good motherhood' and performing 'good researcher-hood', or by Amanda's conflict between performing 'good feminism' by disclosing her maternal status, and performing 'good feminist research' by hiding the reality that she and her participants do not share the world of which they speak. An awareness of the ways in which maternal identity, and its intersection with our identities as researchers, women and feminists, becomes more or less salient during the research process arguably enhances the credibility and transparency of research practice. It also raises pertinent questions about whether the conflict between different identities produces limits on what we can achieve - or whether, in some cases, it may actually hinder our (feminist) research goals. 


\section{References}

Beck, U., \& Beck-Gernsheim, E. (1995). The Normal Chaos of Love. Cambridge: Polity Press.

Brown, K.D. (2011) Elevating the role of race in ethnographic research: navigating race relations in the field, Ethnography and Education, 6 (1), 97-111

Budds, K. (2013). A Critical Discursive Analysis of 'Older' Motherhood. Unpublished PhD Thesis, University of Huddersfield, UK.

Cannold, L. (2004). Declining marriage rates and gender inequity in social institutions: Towards an adequately complex explanation for childlessness. People and Place, 12, 1-11.

Caplan, P.J. \& Hall-McCorquodale, I. (1985). Mother-blaming in major clinical journals. American Journal of Orthopsychiatry, 55(3): 345-353.

Cassell, C.M. (2005). Creating the interviewer: identity work in the management research process, Qualitative Research, 5 (2): 167-179.

Coffey, A. (1999). The Ethnographic Self: Fieldwork and the Representation of Identity. London: Sage

David, M., Davies, J., Edwards, R., Reay, D. and Standing, K. (1996). Mothering and education: reflexivity and feminist methodology. In Breaking Boundaries: Women in Higher Education, Edited by: Morley, L. and Walsh, V. London: Taylor \& Francis.

Emerson, P. \& Frosh, S. (2004). Critical Narrative Analysis in Psychology. Basingstoke: Palgrave Macmillan.

Ellis-Sloan (2012). 'Becoming' A Teenage Mother in the UK. Unpublished doctoral thesis. March 2012. University of Brighton.

Faircloth, C. (in press) Militant Lactivism? Infant Care and Maternal Identity Work in the UK and France. Oxford and New York: Berghahn Books.

Frost, N.A. (2006) Taking the Other Out of Mother: The Transition to Second-Time Motherhood, Unpublished PhD thesis, Birkbeck, University of London.

Finch, J (1984) '"It's great to have someone to talk to": The Ethics and Politics of Interviewing Women' in C. Bell \& H. Roberts (editors) Social Researching. London: Routledge \& Kegan Paul.

Franks, M.(2002). Feminisms and Cross-ideological Feminist Social Research: Standpoint, Situatedness and Positionality - Developing Cross-ideological Feminist Research. Journal of International Women's Studies, 3(2), 38-50.

Ganga, D. \& Scott, S. (2006). Cultural "Insiders" and the Issue of Positionality in Qualitative Migration Research: Moving "Across" and Moving "Along" Researcher-Participant Divides. Forum Qualitative Sozialforschung / Forum: Qualitative Social Research, 7 (3), Art. 7. Available from: http://nbnresolving.de/urn:nbn:de:0114-fqs060379 (Accessed 6 June 2013). 
Gough, B. (2003). Shifting Researcher Positions during a Group Interview Study: A Reflexive Analysis and Re-view. In L. Finlay \& B. Gough (Eds.) Reflexivity: A Practical Guide for Researchers in Health and Social Sciences (pp. 146-160). London: Blackwell.

Hochschild, A.R. (1990). The Second Shift. Canada: HarperCollins.

Hurst, A.L. (2008) A Healing Echo: Methodological Reflections of a Working Class Researcher on Class, The Qualitative Report, 13 (3), 334-352

Holt, A. (2009) Disciplining parents in a youth justice context: negotiating dilemmas of responsibility, blame and identity. Unpublished PhD thesis, University of Brighton.

Jackson, D. \& Mannix, J. (2004). Giving voice to the burden of blame: A feminist study of mothers' experiences of mother blaming. International Journal of Nursing Practice, 10(4):150-158.

Jansson, D. (2010) The head vs. the gut: emotions, positionality, and the challenges of fieldwork with a Southern nationalist movement. Geoforum 41, pp. 19-22

Jeremiah, E. (2006) From Motherhood to Mothering and Beyond: Maternity in Recent Feminist Thought, Journal of the Association for Research on Motherin, 8, 1/2, 21-33.

Lavis, V (2010) Multiple Researcher Identities: Highlighting Tensions and Implications for Ethical Practice in Qualitative Interviewing, Qualitative Research in Psychology, 7 (4), 316-331.

Letherby, G. (1994). Mother or not, mother or what? Problems of definition and identity. Women's Studies International Forum, 17, 525-532.

Letherby, G. (2000). 'Dangerous Liaisons: auto/biography in research and research writing'. In G. LeeTreweek and S. Linkogle (Eds.) Danger in the Field: risk and ethics in social research (pp.91-113). London: Routledge.

Letherby, G. (2002). Claims and Disclaimers: Knowledge, Reflexivity and Representation in Feminist Research, Sociological Research Online, 6 (4). Available from:

http://www.socresonline.org.uk/6/4/letherby.html (Accessed 14 June 2012).

Marshall, H. \& Woollett, A. (2000). Changing youth: An exploration of visual and textual cultural identifications In C. Squire (Ed.) Culture in psychology (pp.118-132). London: Routledge.

Miller, T. (2005). Making Sense of Motherhood. A narrative approach. Cambridge: Cambridge University Press.

Morell, C. (1994). Unwomanly Conduct. London and New York: Routledge.

Morell, C. (2000) Saying no: Women's Experiences with Reproductive Refusal. Feminism and Psychology, 10 (3), pp.313-322.-

Mullings, B. (1999). Insider or outsider, both or neither: some dilemmas of interviewing in a crosscultural setting. Geoforum 30: 337-350.

Oakley, A. (1980) Women confined: towards a sociology of childbirth. Oxford: Martin Robertson. 
Oakley, A. (1981) 'Interviewing women: a contradiction in terms' in N.K. Denzin and Y.L. Lincoln (Eds.) Turning Points in Qualitative Research: Tying Knots in a Handkerchief (pp243-264) Walnut Creek, CA: Altamira Press

Pezella, A.E., Pettigrew, J. \& Miller-day, M. (2012). Researching the researcher as instrument: An excercise in interviewer self reflexivity. Qualitative Research, 12(2):165-185

Phoenix, A., Woollett, A. \& Lloyd, E. (1991). Motherhood: Meanings, Practices and Ideologies. London: Sage.

Raddon, A. (2002) Mothers in the academy, Studies in Higher Education, 27(4), 387-403.

Ramsay, K., and Letherby, G. (2006) 'The experience of academic non-mothers in the gendered university',Gender, Work and Organization, 13 (1), pp.25-44.

Riessman, C.K. (1987). When gender is not enough: women interviewing women. Gender and Society, 1:172-207.

Ryan, L., Kofman, E and Aaron, P (2011) Insiders and outsiders: working with peer researchers in researching Muslim communities, International Journal of Social Research Methodology, 14 (1), 49-60.

Ryan-Flood, R and Gill, R (2010) Secrecy and Silence in the Research Process: Feminist Reflections. Routledge: London

Sarbin, T. R. (1986). Narrative psychology: The Storied Nature of Human Conduct. New York: Praeger.

Takeda , A. (2012) 'Emotional transnationalism and emotional flows: Japanese women in Australia. Women's Studies International Forum,' 35(1), pp. 22-28.

Ward, E (2012) Feminism, New Labour and Lone Motherhood. Unpublished doctoral thesis. University of Brighton.

Weiner-Levy, N. \& Queder, S.A.R (2012) Researching my people, researching the "other": field experiences of two researchers along shifting positionalities, Quality and Quantity, 46 (4), 1151-1166.

Williams, Z. (2012). The backlash against breastfeeding. The Guardian [online]. $25^{\text {th }}$ May 2012. Available from: http://www.guardian.co.uk/lifeandstyle/2012/may/25/breastfeeding-backlash-zoe-williams (Accessed 28 March 2013)

\footnotetext{
${ }^{1}$ Indeed, we struggled ourselves to title this article, given the poverty of language available to describe this status outside of such terms.

${ }^{2}$ While the meaning of 'feminist' is contested and multiplicitous, it is fair to say that the goal of feminist social research is to achieve gender equality by challenging dominant discourses and practices which serve to limit women's opportunities and choices, and enabling new, more empowering ones. For a detailed overview of different feminisms in social research, see Franks (2002); for a detailed overview of different feminist perspectives on motherhood, see Jeremiah (2006).

${ }^{3}$ Such tensions are not exclusive to those who are mothers: Ramsay and Letherby (2006) identify some of the conflicts experienced by non-mothers in academia, not least the expectation of hyper-productivity and hyper-achievement, because it is assumed they chose academia over motherhood.
} 
Tables for QRJ Article 'Maternal Identity'

TABLE 1: Second-time Mothering: Table of Participants

\begin{tabular}{|l|l|l|l|l|l|}
\hline & Participant & $\begin{array}{l}\text { Age } \\
\text { Band }\end{array}$ & Marital Status & Ethnicity & Employment \\
\hline 1 & Karen & $31-35$ & Married & White British & Journalist \\
\hline 2 & Gemma & $31-35$ & Married & White British & Dentist \\
\hline 3 & Rachel & $31-35$ & Married & White British & Engineer \\
\hline 4 & Hannah & $31-35$ & Married & White British & Lawyer \\
\hline 5 & Camilla & $36-40$ & Co-habiting & North American & Interior Designer \\
\hline 6 & Tina & $26-30$ & Co-habiting & White British & Psychotherapist \\
\hline 7 & Dominique & $31-35$ & Co-habiting & North American & Business Executive \\
\hline 8 & Nollaig & $31-35$ & Married & White British & Research student \\
\hline
\end{tabular}

TABLE 2: Mothering troublesome young people: Table of Participants

\begin{tabular}{|c|c|c|c|c|c|}
\hline & Participant & $\begin{array}{l}\text { Age } \\
\text { Band }\end{array}$ & Marital Status & Ethnicity & Employment \\
\hline 1 & Mary & $41-45$ & Co-habiting & White British & Nail Technician (p/t) \\
\hline 2 & Bee & $41-45$ & Lone parent & White British & Receptionist \\
\hline 3 & Katy & $51-56$ & Married & White British & Administrator \\
\hline 4 & Claire & $36-40$ & Lone parent & White British & Unemployed/Homemaker \\
\hline 5 & Penny & $36-40$ & Married & White British & Unemployed/Homemaker \\
\hline 6 & Dee & $31-35$ & Lone parent & White British & Unemployed/Homemaker \\
\hline 7 & Lynn & $41-45$ & Lone parent & Black Jamaican & Unemployed/Homemaker \\
\hline 8 & Melanie & $41-45$ & Married & White British & Sales assistant $(p / t)$ \\
\hline 9 & Jan & $41-45$ & Lone parent & - & - \\
\hline 10 & Carole & $41-45$ & Lone parent & - & - \\
\hline 11 & Donna & $41-45$ & Married & White British & Unemployed/Homemaker \\
\hline 12 & Sue & $41-45$ & Lone parent & White British & Voluntary worker \\
\hline 13 & Sally & $41-45$ & Lone parent & - & - \\
\hline 14 & Louise & $41-45$ & Lone parent & White British & Unemployed/Homemaker \\
\hline 15 & Tina & $41-45$ & Lone parent & White British & Unemployed/Homemaker \\
\hline 16 & Amanda & $31-35$ & Co-habiting & White British & Research student \\
\hline
\end{tabular}

\footnotetext{
${ }^{\mathrm{i}}$ All participant names are pseudonyms, which the exception of the researchers, Nollaig and Amanda.
} 